\title{
HABENARIA AGASTHYAMALAIANA (ORCHIDACEAE), A NEW TERRESTRIAL ORCHID FROM THE SOUTHERN WESTERN GHATS, INDIA
}

\author{
JeEwan Singh JalaL ${ }^{1 *}$, J. Jayanthi ${ }^{2} \&$ Suresh Kumar P. ${ }^{3}$ \\ ${ }^{1,2}$ Botanical Survey of India, Western Regional Centre, 7-Koregaon Road, Pune-411001, India \\ ${ }^{3}$ Jawaharlal Nehru Tropical Botanic Garden and Research Institute, Palode, Kerala-695562, India \\ *Corresponding author: jeewan.orchid@gmail.com
}

\begin{abstract}
AвSTRACT. Habenaria agasthyamalaiana, a new species of terrestrial orchid is described from Shendurney Wildlife Sanctuary of Agasthyamalai biosphere reserve, a part of the South-western Ghats. This species is morphologically similar to Habenaria crinifera. Detailed description and photographs are provided for identification of this new taxon.
\end{abstract}

KEY wORDS: Agasthyamalai, Kerala, Kollam, New species, Shendurney wildlife sanctuary, Western Ghats

Introduction. The mountain chain of the Western Ghats biogeographic zone older than the Himalaya has geomorphic features of immense importance with unique geology, flora and fauna and ecology. The Western Ghats forest ecosystem moderates the tropical climate of the region and has an exceptionally high level of biological diversity and endemism. It is recognized as one of the world's eight 'hottest hotspots' of biological diversity along with Sri Lanka. The Western Ghats is an "Evolutionary Ecotone" and the region demonstrates speciation related to the breakup of the ancient landmass of Gondwanaland and is hence considered as a cradle for biological evolution. More than 7,000 of the plant species have been recorded from the Western Ghats with the number of endemics estimated to be 2,253 (Nayar et al. 2014). The historical human presence in the Western Ghats makes it an area of high conservation interest (Joshi et al. 2017). The region harbors two Biosphere Reserves, 15 National Parks, 52 Wild Life Sanctuaries, nine Tiger Reserves and 39 UNESCO World heritage sites. During the recent orchid exploration in the Shendurney Wildlife Sanctuary, Kerala, a part of the Agasthyamalai biosphere reserve in the southern Western Ghats, the first author located an interesting Habenaria population. This entity was morphologically similar to Habenaria crinifera Lindl., however we studied it because of significant morphological differences.

Habenaria Willdenow (1805: 5) (Orchidinae, Orchidoideae, Orchidaceae) is a large genus of approximately 883 terrestrial species (Govaerts et al. 2018) distributed throughout the tropical and subtropical regions of the Old and New World (Pridgeon et al.
2001), with centers of diversity in Brazil, southern and central Africa and East Asia (Kurzweil \& Weber 1992). Most species are perennial, geophytes, with a growth associated with a wet season followed by a dormant period in the form of an underground root tuber during the dry season (Batista et al. 2013). There are 69 species reported in India and 39 of them are found in the Western Ghats, with 22 being endemic (Nayar et al. 2014, Kumar et al. 2016). Kerala is also one of the biodiversity rich state harboring 258 orchid species of which 29 species of Habenaria (Nayar et al. 2014). Specimens of this entity were collected and measurements were made using fresh material. The flowers were dissected and examined under the Stereozoom microscope SZ61 and description was written. The entity is characteristic by conspicuous flowers, a tripartite lip with a bifurcate midlobe which is shorter than lateral lobes. The specimen was compared with the allied species Habenaria crinifera and Habenaria plantaginea Lindl. (Table 1). Based on the examination of a fresh specimen and comparison with the known species of the genus, we conclude that our taxon represents new undescribed species which is described here.

\section{TAXONOMIC TREATMENT}

Habenaria agasthyamalaiana Jalal, Jayanthi \& Sureshkumar, sp. nov. Fig. 1-5A.

TYPE: INDIA. Kerala: Kollam District, Shendurney Wildlife Sanctuary, on the way to Rosemala, $550 \mathrm{~m}$ elev., 12 October 2018, J.S.Jalal 197753 (holotype $\mathrm{BSI}$ !; isotype BSI!). 
TABLE 1. Comparative morphological characters and distribution range of Habenaria agasthyamalaiana sp. nov., H. crinifera and $H$. plantaginea.

\begin{tabular}{|c|c|c|c|}
\hline Character & H. agasthyamalaiana & H. crinifera Lindl. & H. plantaginea Lindl. \\
\hline Habit & Terrestrial & Terrestrial or epiphytic & Terrestrial \\
\hline Height & $35-40 \mathrm{~cm}$ & $15-30 \mathrm{~cm}$ & $20-40$ \\
\hline Flowers in inflorescence & $8-11$ & $2-9$ & up to 16 \\
\hline Floral bracts & lanceolate, entire at margin, 1 -veined & $\begin{array}{l}\text { ovate, serrulate at margin, } \\
\text { 3-veined }\end{array}$ & $\begin{array}{l}\text { ovate-lanceolate, entire at } \\
\text { margin, } 1 \text {-veined }\end{array}$ \\
\hline Dorsal sepal & ovate, white & orbicular, greenish & broadly ovate, white \\
\hline Lateral sepals & obliquely ovate, white & broadly ovate, white & obliquely lanceolate-ovate, white \\
\hline Petals & oblong-oblanceolate & linear-pandurate & elliptic-oblanceolate \\
\hline Lip & 3-lobed, distinctly clawed (Fig. 5A) & $\begin{array}{l}\text { 3-lobed, distinctly clawed (Fig. } \\
\text { 5B) }\end{array}$ & $\begin{array}{l}\text { 3-lobed, obscurely clawed (Fig. } \\
5 \mathrm{C})\end{array}$ \\
\hline Side lobes of lip & $\begin{array}{l}\text { longer than midlobe, obliquely } \\
\text { flabellate, long acuminate at } \\
\text { divergent end of the apex }\end{array}$ & $\begin{array}{l}\text { shorter than midlobe, obliquely } \\
\text { flabellate-narrow, long caudate } \\
\text { at divergent end of the apex }\end{array}$ & $\begin{array}{l}\text { almost equal to midlobe, } \\
\text { obliquely flabellate, acute- } \\
\text { obtuse at divergent end of the } \\
\text { apex }\end{array}$ \\
\hline Midlobe of lip & $\begin{array}{l}\text { divided into } 2 \text { equal to unequal } \\
\text { lobules; lobules oblong, obtuse at } \\
\text { apex }\end{array}$ & $\begin{array}{l}\text { divided into } 2 \text { lobules, obliquely } \\
\text { flabellate-narrow, long caudate } \\
\text { at divergent end of the apex }\end{array}$ & $\begin{array}{l}\text { not divided, acute-obtuse at } \\
\text { apex }\end{array}$ \\
\hline Spur & $4.5 \mathrm{~cm}$ long, without ligule at mouth & $\begin{array}{l}2.7-3.5 \mathrm{~cm} \text {, with a long erect } \\
\text { ligule at mouth }\end{array}$ & $\begin{array}{l}3-3.5 \mathrm{~cm} \text { long, with ligule at } \\
\text { mouth }\end{array}$ \\
\hline Distribution & southern Western Ghats & $\begin{array}{l}\text { throughout Western Ghats \& Sri } \\
\text { Lanka }\end{array}$ & $\begin{array}{l}\text { throughout India, Bangladesh, } \\
\text { Bhutan, Nepal, Sri Lanka }\end{array}$ \\
\hline
\end{tabular}

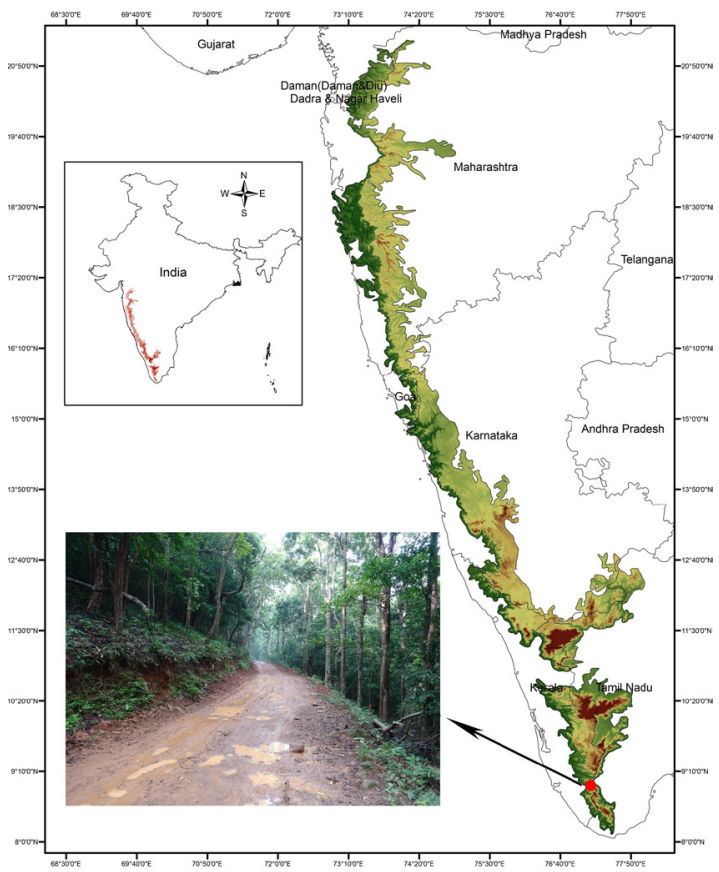

FIGURE 1. Distribution map of Habenaria agasthyamalaiana sp. nov. in Western Ghats (DEM data source- Earth Explorer Aster Global, USA; map prepared by J. S. Jalal in ArcGIS 10.5).

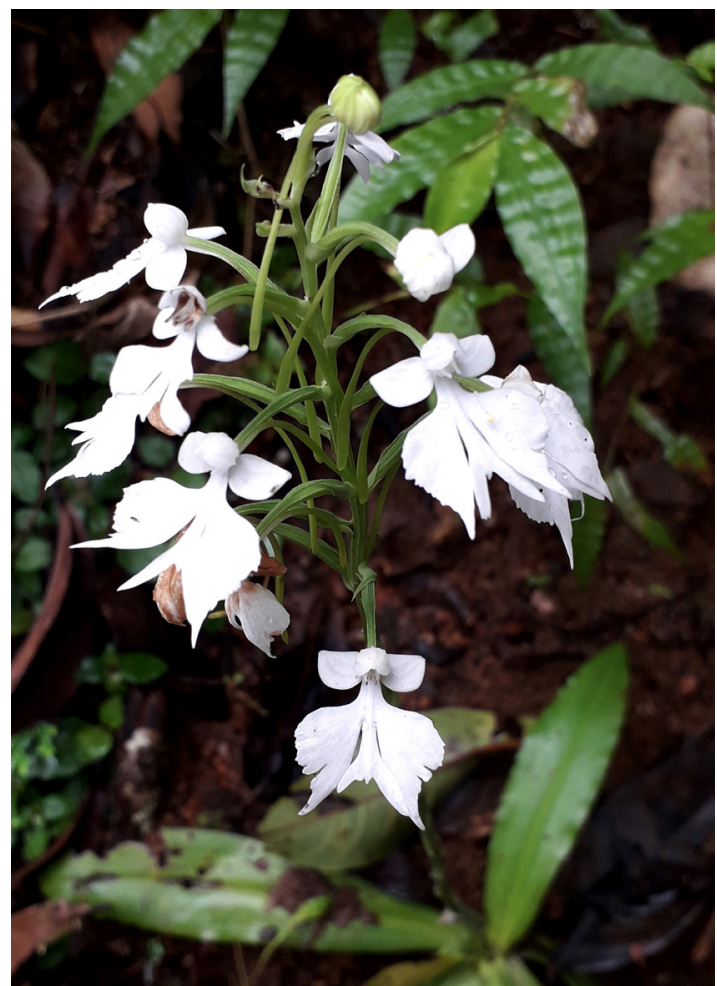

FIGURE 2. Habenaria agasthyamalaiana in natural habitat showing close up of inflorescence. Photos by J. S. Jalal. 


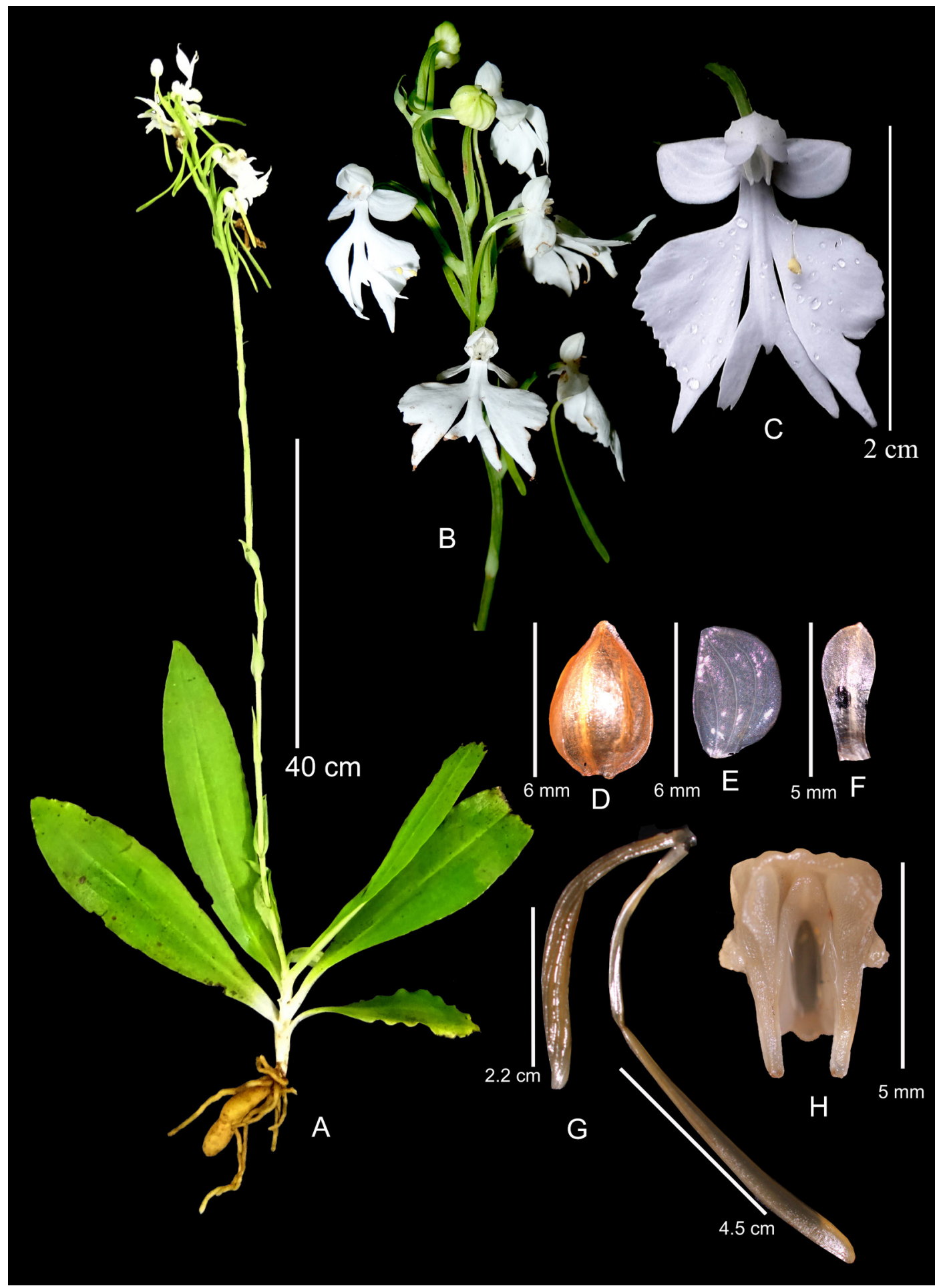

Figure 3. Habenaria agasthyamalaiana A. Habit. B. Inflorescence showing view of flowers. C. Front view of flower. D. Dorsal sepal. E. Lateral sepal. F. Petal. G. Ovary with pedicel and spur. H. View of column. Photos by J. S. Jalal. 

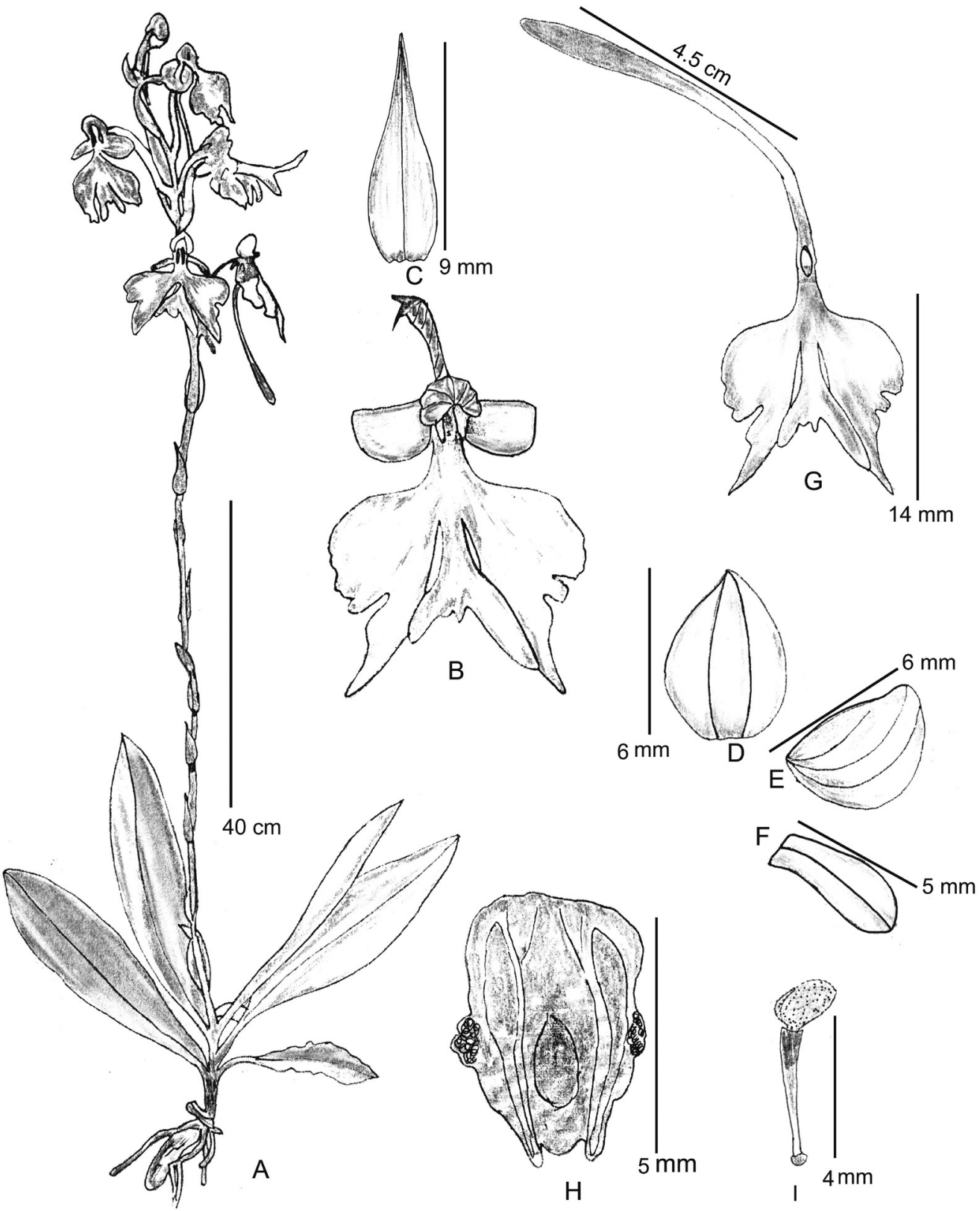

Figure 4. Habenaria agasthyamalaiana A. Habit. B. View of flower showing lip. C. Floral bract. D. Dorsal sepal. E. Lateral sepal. F. Petal. G. Lip and spur. H. View of column. I. Pollinia. Drawing by J. S. Jalal.

Diagnosis: Habenaria agasthyamalaiana is distinguishable by having subradical leaves, with conspicuous flowers, with 3-lobed lip, bifurcate midlobe shorter than lateral lobes. It is closely similar to $H$. crinifera but differs by having up to 11 flowers in inflorescence, floral bracts entire at margin, side lobes of lip longer than midlobe, side lobes acuminate at apex and midlobe bifurcate with obtuse lobes (vs. side lobes and midlobe of lip with long caudate apex).

Terrestrial herbs, 35-40 $\mathrm{cm}$ high (including 


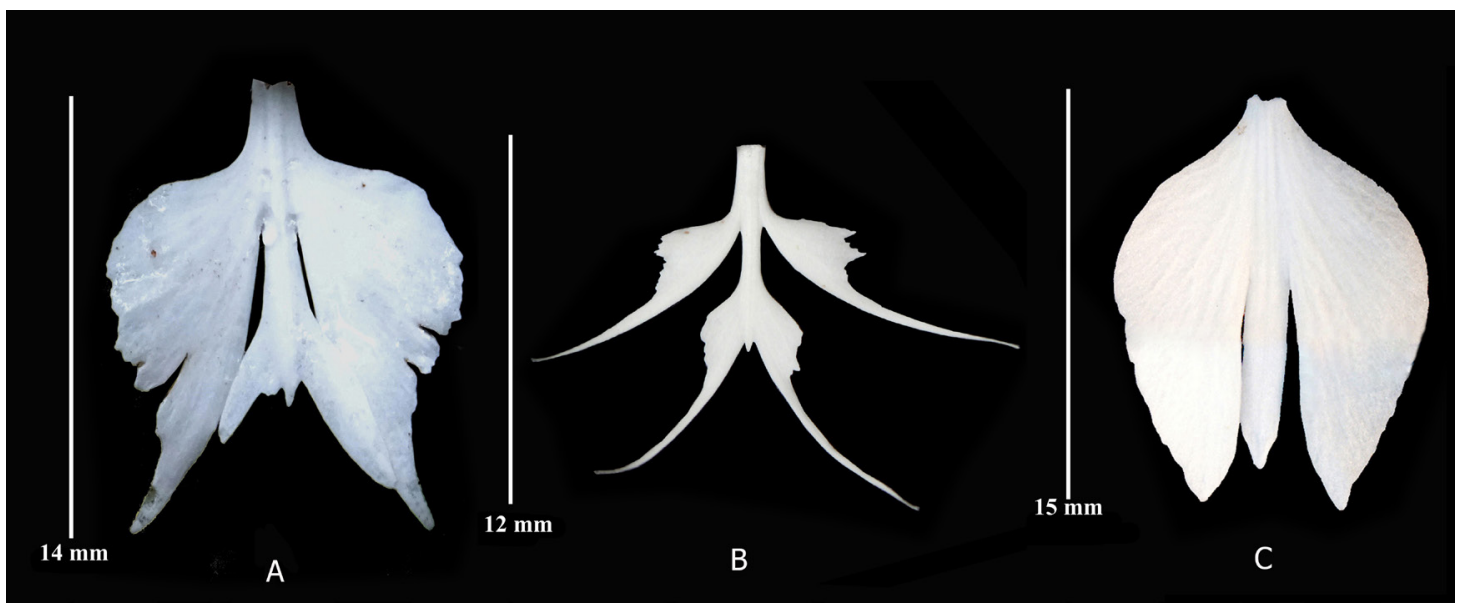

Figure 5. Comparative lip morphology A. Habenaria agasthyamalaiana B. H. crinifera (J.S.Jalal 195200 BSI) C. H. plantaginea (J.S.Jalal 200889 BSI). Photos by J. S. Jalal.

inflorescence). Tuber solitary, $4.0 \times 1.5 \mathrm{~cm}$, oblong in outline, lateral roots 9 , arising above the tuber, 3 $\mathrm{mm}$ in diameter, one of the roots ending in tuberoids. Leaves 5-7, subradical, clustered at base, 5-15 × 1-3 $\mathrm{cm}$, oblong-elliptic, entire, wavy margin, tapering and sheathed at base, acute at apex, 3-veined with midrib prominent than lateral veins. Inflorescence terminal, racemose, 5-6 cm long, 8-11-flowered. Peduncle 23-29 cm, ribbed, with $6-11$ bracts. Peduncular bracts foliaceous, larger at basal portion, becoming smaller towards apex, 0.7-3.5 × 0.4-1.0 $\mathrm{cm}$, ovate-lanceolate, entire margin, semiamplexicaul at base, acuminate at apex, 1-veined. Floral bracts 9 $\times 4 \mathrm{~mm}$, lanceolate, entire margin, semiamplexicaul at base, acuminate at apex, 1-veined, shorter than ovary, and adnate to it. Flowers resupined, white, 2 $\mathrm{cm}$ across. Ovary with pedicel $2.2 \mathrm{~cm}$ long, green, swollen at basal portion, narrowed at upper portion, ribbed, curved, at $90^{\circ}$ from the rachis. Pedicel $1 \mathrm{~mm}$ long. Dorsal sepal cucullated, $6 \times 4 \mathrm{~mm}$, cymbiform, ovate, entire margin, truncate at base, obtuse at apex, 2-veined. Lateral sepals spreading, $6 \times 5 \mathrm{~mm}$, obliquely ovate, entire margin, truncate at base, obtuse at apex, 3-veined. Petals $5 \times 2 \mathrm{~mm}$, oblongoblanceolate, entire margin, truncate at base, apiculate at apex, 1-veined. Lip 3-lobed, clawed, claw $4 \mathrm{~mm}$ long; lateral lobes longer than midlobe, parallel to midlobe, curved outwards, $10-11 \times 8 \mathrm{~mm}$, obliquely flabellate, entire proximal margin, irregularly dentate distal margin, cuneate at base, curved outwards, long acuminate at apex; midlobe shorter than lateral lobes, entire margin, divided into 2 equal to unequal lobes, bifurcate-obtuse at apex, with triangular apicule at centre; spur much longer than ovary, $4.5 \mathrm{~cm}$ long, greenish-white, club-shaped, cylindrical. Column 5 $\times 2 \mathrm{~mm}$, white, narrow at downwards and broad at upper portion. Connective white, shallowly undulate at apex. Anthers 2, whitish, straight; white anther canal, $4 \mathrm{~mm}$ long white. Rostellum slightly shorter than anthers, white, fleshy, adnate to the mouth of the spur. Auricles white, small, verrucose. Pollinia 2, yellow, $4 \mathrm{~mm}$ long, with round viscidium. Fruits unknown.

FLOWERING: October.

Distribution: India: Kerala, Kollam district, Shendurney Wildlife sanctuary, way to Rosemala (Fig. 1).

Habitat and ecology: The new species is found growing along the moist slopes of southern moist mixed deciduous forests on the way to Rosemala at about $550 \mathrm{~m}$ of elevation. This habitat is dominated by species as Oplismenus compositus (L.) P.Beauv. (Poaceae), Ophiorrhiza rugosa Wall. (Rubiaceae), Selaginella sp. (Selaginellaceae).

Eponymy: The specific epithet is named after the Agasthyamalai Biosphere Reserve where is the type locality of this new species.

THREATS: A small population was found growing in a small area of 1 square meter. A potential threat could be the expansion of the road leading to the Rosemala area. 
This new species belongs to section Plantagineae and characterized by the presence of subradical leaves, clustered at base, medium flower size, entire petals, 3-lobed lip, side lobes large, slightly to widely crenatedentate to erose at margin. Habenaria agasthyamalaiana is very similar to $H$. crinifera but it differs by having up to 11 flowers in inflorescence, floral bracts entire at margin, side lobes of lip longer than midlobe (Fig. 5B), side lobe acuminate at apex and midlobe of lip bifurcate with obtuse apex. It also seems to H. plantaginea Lindl. but it differs by having distinctly clawed lip, divided midlobe of lip, long acuminate lateral lobes whereas in $H$. plantaginea (Fig. 5C) the lip is indistinctly clawed, the midlobe of lip is undivided and lateral lobes of lip acute at apex. A detailed comparison of these species is provided in Table 1.

ACKNOWLEDGEMENTS. The first and second authors are thankful to Dr. A. A. Mao, Director, Botanical Survey of India and Dr. P. Lakshminarasimhan, Scientist 'E' \& HoO, Botanical Survey of India, Western Regional Centre, Pune for facilities and encouragement. Dr. K. N. Gandhi, Hardvard University Herbaria for valuable suggestions on specific epithet. The third author is thankful to Director, Jawaharlal Nehru Tropical Botanic Garden \& Research Institute, Kerala for his help and also thank the authorities of Forest department, Kerala for granting permission (Letter No.WL $10-55508 / 2017$ dated 03/07/2018).

\section{LiteratuRe Cited}

Batista, J. A. N., Borges, K. S., de Faria, M. W. F., Proite, K., Ramalho, A. J., Salazar, G. A. \& van den Berg, C. (2013). Molecular phylogenetics of the species-rich genus Habenaria (Orchidaceae) in the New World based on nuclear and plastid DNA sequences. Molecular Phylogenetics and Evolution, 67, 95-109. http://dx.doi. org/10.1016/j.ympev.2013.01.008.

Govaerts, R., Bernet, P., Kratochvil, K., Gerlach, G., Carr, G., Alrich, P., Pridgeon, A. M., Pfahl, J., Campacci, M. A., Baptista, D. H., Tigges, H., Shaw, J., Cribb, P., George, A., Kreuz, K. \& Wood, J. (2018). World Checklist of Orchidaceae. Facilitated by the Royal Botanic Gardens, Kew. Retrieved on 18 December 2018 from http:// wcsp.science.kew.org/

Joshi, M., Charles, B., Ravikanth, G. \& Arvind, N. A. (2017). Assigning conservation value and identifying hotspots of endemic rattan diversity in the Western Ghats, India. Plant Diversity, 39, 263-272. http://dx.doi. org/10.1016/j.pld.2017.08.002.

Kumar, P., Prabhukumar, K. M., Nirmersh, T. K., Sreekumar, V. B., Hareesh, V. S. \& Balachandran, I. (2016). Habenaria sahyadrica (Orchidaceae, Orchideae) a new species from the Western Ghats (India) with critical notes on allied taxa. Phytotaxa, 244 (2), 196-200. https://doi.org/10.11646/phytotaxa.244.2.8

Kurzweil, H. \& Weber, A. (1992). Floral morphology of Southern African Orchideae. II. Habenariinae. Nordic Journal of Botany, 12, 39-61.

Nayar, T. S., Sibi, M. \& Beegam, A. R. (2014). Flowering plants of the Western Ghats, India. Palode, India: Jawaharlal Nehru Tropical Botanic Garden and Research Institute.

Pridgeon, A. M., Cribb, P. J., Chase, M. C. \& Rasmussen, F. N. (2001). Genera Orchidacearum, Vol. 2, Orchidoideae (part 1). Oxford: Oxford University Press. 